\title{
Adult Still's disease: An unusual case with atypical skin and histopathological findings
}

Erișkin Still hastalığı: Atipik deri ve histopatolojik bulguları ile alıșılmadık bir olgu

\section{Ayșe Tunçer Vural, ๑ Deren Özcan, ๑ Merih Tepeoğlu*}

Bașkent University Faculty of Medicine, Department of Dermatology; *Department of Pathology, Ankara, Turkey

\begin{abstract}
Adult Still's disease is a rare, acute systemic inflammatory disease characterized by a sudden rising fever, arthralgia/arthritis, neutrophilic leukocytosis and a typical salmon-colored macular or maculopapular rash associated elevated fever. Recently, atypical skin lesions with broad spectrum clinical features and distinctive histopathological findings have been reported in a rare case with active disease. Herein, we report an unusual case of Adult Still disease was presented and the characteristic features of atypical disease were highlighted. Keywords: Adult-onset Still disease, atypical eruption, necrotic keratinocyte, persistent pruritic papules and plaques

\section{Öz}

Erişkin Still hastalı̆ı aniden yükselen ateş, artralji/artrit, nötrofilik lökositoz ve ateşin yükselmesiyle birlikte ortaya çıkan tipik somon rengi maküler veya makülopapüler döküntü ile karakterize, sebebi bilinmeyen, nadir görülen akut sistemik enflamatuvar bir hastalıktır. Yakın zamanda, aktif hastalığı olan nadir bir olguda geniş spektrumda klinik özellikler ve kendine özgü histopatolojik bulgular ile seyreden atipik deri lezyonları raporlanmıştır. Burada, alışımadık bir Erişkin Still hastalığı olgusu sunulmuş ve atipik hastalığın karakteristik özellikleri vurgulanmıştır. Anahtar Kelimeler: Erişkin Still hastalığı, atipik erüpsiyon, nekrotik keratinosit, persistan pruritik papül ve plaklar
\end{abstract}

\section{Introduction}

Adult-onset Still's disease (AOSD) is an uncommon, acute systemic inflammatory disorder that is characterized by intermittent spiking fever, arthralgia/arthritis, neutrophilic leukocytosis and an evanescent rash'. The disease is often accompanied by sore throat, lymphadenopathy, hepatosplenomegaly and hyperferritinemia. Pleuritis, pericarditis, renal dysfunction and reactive hemophagocytic syndrome may also be seen². The onset is between 15 and 35 years of age in $75 \%$ of the cases and it affects women more frequently ${ }^{3}$. While the precise etiology of AOSD remains unknown, evidence suggests activation of macrophages and natural killer cells possibly caused by viral or persistent infection ${ }^{4,5}$.

Classical rash of AOSD is a salmon-pink or erythematous, evanescent, usually nonpruritic, maculopapular exanthema predominantly involving the trunk and limbs which appears with the onset of fever-up and fades during afebrile episode ${ }^{6}$. Recently, atypical skin lesions consisting of persistent, erythematous, brown or violaceous papules and plaques with various configurations have been reported in sporadic cases with active $\mathrm{AOSD}^{6-8}$.

Address for Correspondence/Yazışma Adresi: Deren Özcan MD, Başkent University Faculty of Medicine, Department of Dermatology, Ankara, Turkey Phone: +90 5334613294 E-mail: derenozcan@yahoo.com.tr Received/Geliş Tarihi: 08.05.2019 Accepted/Kabul Tarihi: 21.04.2020 ORCID: orcid.org/0000-0002-7450-6886 


\section{Case Report}

A 41-year-old woman was referred for a 2-weeks history of pruritic rash on her face, extremities and back. She had been admitted to department of rheumatology owing to malaise, arthralgia in the knees and elbows, sore throat, and spiking fever (up to $39.5^{\circ} \mathrm{C}$ ). The detailed review of systems regarding particularly the infections, malignancies and connective tissue diseases was otherwise unremarkable. Dermatologic examination revealed bilateral, tender, erythematous patches on the periorbital regions, elbows and knees, erythematous plaques and papules on the dorsum of the hands, fingers and back, and a linear erythematous plaque of $5 \times 1 \mathrm{~cm}$ in size over the right scapula (Figure 1, 2). Laboratory results were notable for leukocytosis (20.29×103 cells/ $\mathrm{uL})$, neutrophilia (17.5×103 cells/uL), elevated C-reactive protein (273 $\mathrm{mg} / \mathrm{L}$ ), abnormal liver function tests (aspartate aminotransferase: 83 $\mathrm{U} / \mathrm{L}$, alanine aminotransferase: $49 \mathrm{U} / \mathrm{L}$ ) and hyperferritinemia (>1500 $\mathrm{ng} / \mathrm{mL}$ ). Rheumatoid factor, antinuclear antibody and extractable nuclear antigen profiles were negative. Blood, urine and throat cultures for bacteria were negative. Serologic evaluation including hepatitis B surface antigen (HBsAg), anti-HBs antibody, anti-hepatitis $C$ virus (anti-HCV) antibody, cytomegalovirus-immunoglobulin $M$ $(\lg M)$ and $\lg G$ antibodies, Epstein-Barr virus-lgM and $\lg G$ antibodies, parvovirus B19 IgM and IgG antibodies, and brucella agglutination test were all negative. No pathology was noted on chest X-ray. Reactive

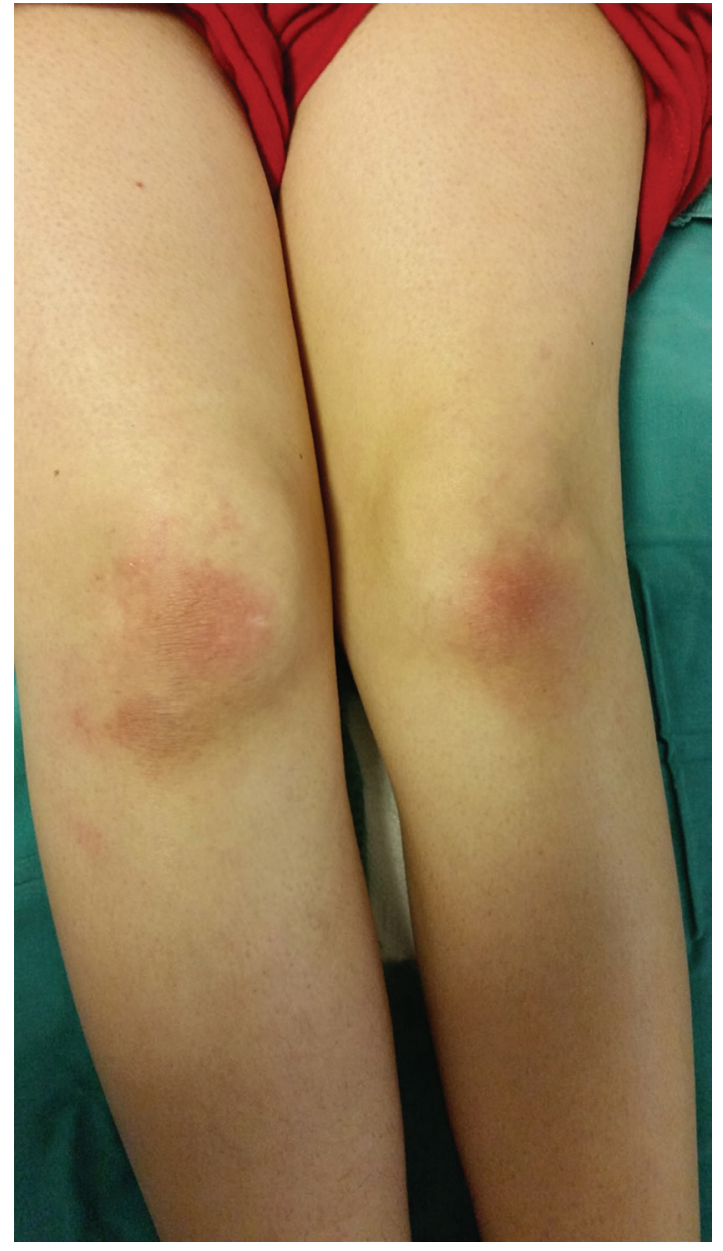

Figure 1. Bilateral erythematous patches on the knees cervical lymphadenopathy was seen on ultrasonography. Punch biopsy specimens were obtained from the back and the right elbow. Histopathology disclosed slight hyperkeratosis with numerous necrotic keratinocytes in the upper epidermis, basal vacuolar degeneration and neutrophilic perivascular inflammation (Figure 3).

The patient was diagnosed with AOSD ${ }^{1}$. She was started on treatment with oral methylprednisolone $(40 \mathrm{mg} / \mathrm{d})$, cetirizine $(10 \mathrm{mg} / \mathrm{d})$ and mometasone furoate cream. The fever subsided, arthralgia and rash regressed within 3 days. The disease was reactivated after 3 weeks, when the methylprednisolone dose was gradually tapered to $24 \mathrm{mg} / \mathrm{d}$. Hydroxychloroquine $(400 \mathrm{mg} / \mathrm{d}$ ) and oral methotrexate $(12.5 \mathrm{mg} /$ wk) were added to the treatment. The clinical and laboratory findings

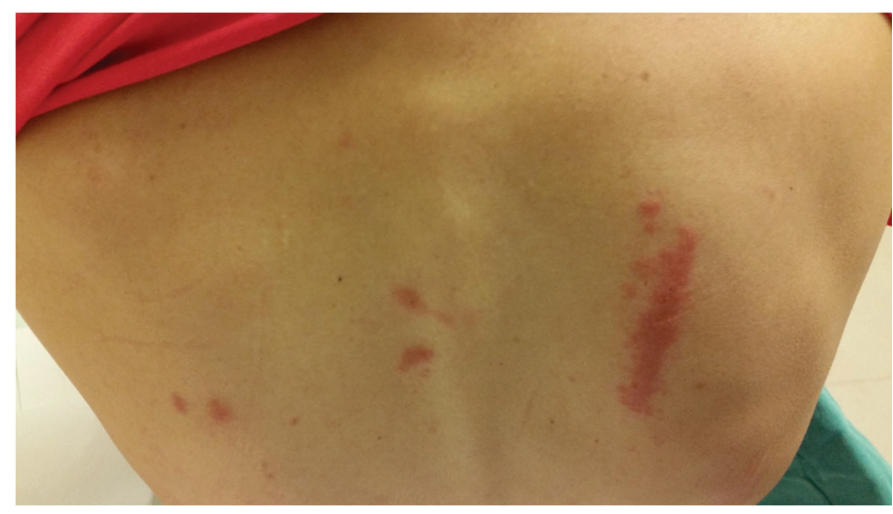

Figure 2. Erythematous papules on the back and a linear erythematous plaque over the right scapula

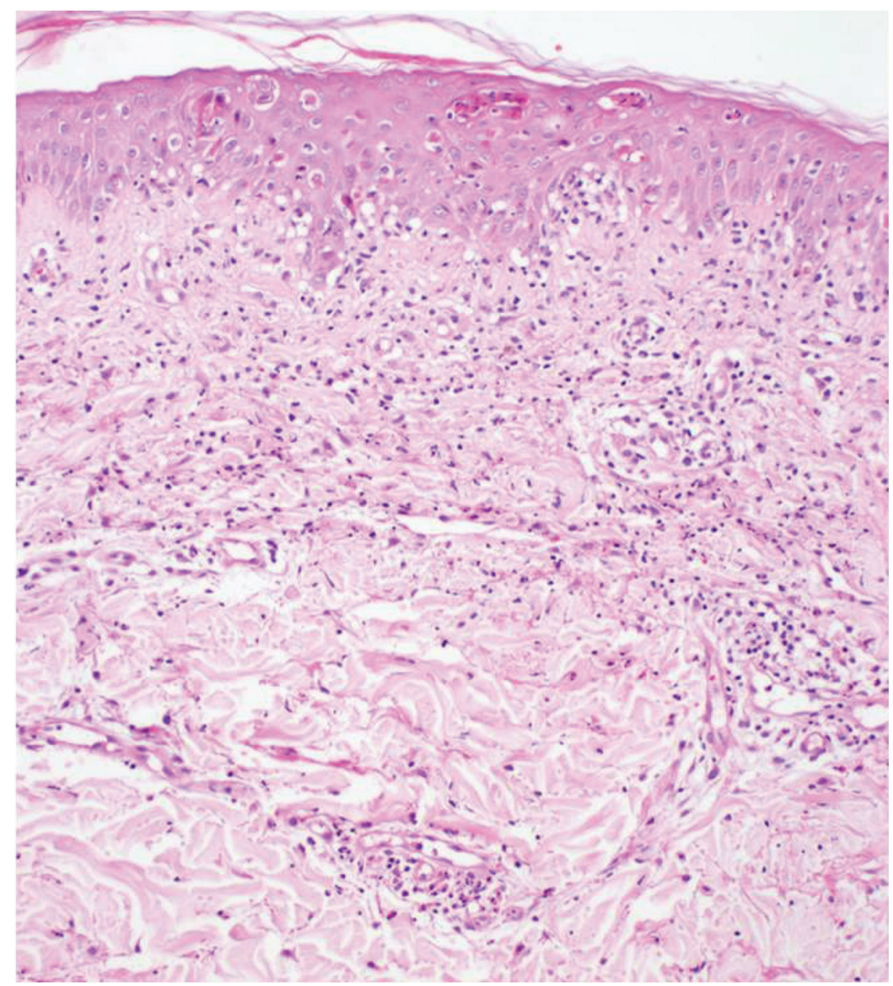

Figure 3. Slight hyperkeratosis with numerous necrotic keratinocytes in the upper epidermis, basal vacuolar degeneration and neutrophilic perivascular inflammation (hematoxylin-eosin, original magnification, $\mathrm{x} 20)$ 
improved during the next 15 days. Informed consent was obtained from the patient.

\section{Discussion}

Atypical skin eruption of AOSD is usually severely pruritic, tends to be widespread, and mostly distributed over the face, neck, trunk and extensor sites of extremities. A linear or flagellate pattern is frequently observed which is attributed to Koebner's phenomenon. Other configurations include urticarial erythema, lichenoid papules, dermatomyositis-like, prurigo pigmentosa-like and lichen amyloidosislike rashes ${ }^{3,6}$. The atypical skin lesions often present in addition to the classical rash but may also be the only cutaneous manifestation. More than one morphology or distribution pattern can be observed in some patients ${ }^{7}$.

The diagnosis of AOSD is challenging and based on the exclusion of infections, malignancies and connective tissue diseases. Among the proposed diagnostic criteria, Yamaguchi et al. ${ }^{1}$ criteria has the highest sensitivity $(93.5 \%)$ and is the most widely used one. Major criteria are fever ( $\geq 39{ }^{\circ} \mathrm{C}, \geq 1$ week) arthralgia/arthritis ( $\geq 2$ weeks), classical skin rash, leukocytosis ( $\geq 10.000 / \mathrm{mm}^{3}$ with $\geq 80 \%$ granulocytes). Minor criteria are sore throat, lymphadenopathy, hepatomegaly/ splenomegaly, abnormal liver function studies, negative rheumatoid factor and antinuclear antibody. The presence of five or more criteria, including at least 2 major criteria is essential for the diagnosis ${ }^{1,7}$. While the classical rash which has $87 \%$ sensitivity and $99 \%$ specificity is well-known, the atypical skin lesions are unfamiliar and have a wide spectrum of clinical presentation which results in under-recognition and thus delayed diagnosis s,7,8. $^{4}$.

The treatment includes non-steroidal anti-inflammatory drugs, systemic corticosteroids, hydroxychloroquine, cyclosporine, methotrexate and biological agents (anakinra and tocilizumab) ${ }^{9}$. The presence of atypical rashes have been reported to indicate resistance to treatment and more severe disease, and thus may require more potent or maintenance immunosuppressive therapy to control the disease ${ }^{7,10}$. The course of AOSD can be self-limiting, polycyclic with complete remission between flares or chronic with a predominance of articular symptoms leading to joint destruction. The extensive cutaneous involvement, particularly the dermatomyositis-like eruption has been found to have a poorer outcome $e^{6,7}$.

The persistent skin lesions of AOSD display a wide spectrum of clinical features and should be differentiated from urticarial vasculitis, lichen planus, dermatomyositis, lichenoid or violaceous rashes of lupus erythematosus, cutaneous graft-versus-host disease, lichen amyloidosis, prurigo pigmentosa and maculopapular or lichenoid drug eruption? Histopathological findings of classical rash are non-specific and comprise a normal epidermis overlying a mixed mild perivascular inflammation of the upper dermis composed of lymphocytes and neutrophils ${ }^{4}$. In contrast, atypical skin lesions show distinct histolopathological features including dyskeratotic and necrotic keratinocytes, singly or in aggregates, mostly in the superficial epidermis with neutrophilic infiltrate in the dermis ${ }^{6,10}$. The highly distinctive histopathologic features will allow those atypical skin lesions to be readily diagnosed.
In our case the presence of nonevanescent erythematous papules, linear plaques, dermatomyositis-like lesions, leukocytosis, abnormal liver function tests, hyperferritinemia, lymphadenopathy and histopathological features namely necrotic keratinocytes in the upper epidermis in the setting of sore throat, arthralgia and high spiking fever raised the suspicion of AOSD. The infectious, malignant, lymphoproliferative, and autoimmune disorders were excluded based on the clinical, laboratory, and histopathological examination, and the diagnosis of AOSD was made as per Yamaguchi et al. ${ }^{1}$ criteria. So, with early and appropriate treatment the clinical and laboratory findings improved in a short period of time.

Although rare and not a component of the diagnostic criteria of AOSD, it is important to recognize the cutaneous spectrum and unique histopathological features of atypical skin lesions for the accurate diagnosis and appropriate treatment.

\section{Ethics}

Informed Consent: Informed consent was obtained from the patient. Peer-review: Externally and internally peer-reviewed.

\section{Authorship Contributions}

Surgical and Medical Practices: A.T.V., D.Ö., M.T., Consept: A.T.V., D.Ö., Design: A.T.V., D.Ö., Data Collection or Processing: A.T.V., D.Ö., Analysis or Interpretation: A.T.V., D.Ö., M.T., Literature Search: A.T.V., D.Ö., Writing: A.T.V., D.Ö.

Conflict of Interest: The authors have no conflict of interest to disclose. Financial Disclosure: The authors declared that this study received no financial support.

\section{References}

1. Yamaguchi $M$, Ohta $A$, Tsunematsu $T$, et al: Preliminary criteria for classification of adult Still's disease. J Rheumatol 1992;19:424-30.

2. Altınsoy $B$, Ertürk $A$ : Plörezinin nadir bir nedeni olan erişkin Still hastalığı: olgu sunumu. Cumhuriyet Med J 2009;31:448-51.

3. Cozzi A, Papagrigoraki A, Biasi D, Colato C, Girolomoni G: Cutaneous manifestations of adult-onset Still's disease: a case report and review of literature. Clin Rheumatol 2016;35:1377-82

4. Yamamoto T: Cutaneous manifestations associated with adult-onset Still's disease: Important diagnostic values. Rheumatol Int 2012;32:2233-7.

5. Siddiqui M, Putman MS, Dua AB: Adult-onset Still's disease: current challenges and future prospects. Open Access Rheumatol 2016;8:17-22.

6. Lee JY, Hsu CK, Liu MF, Chao SC: Evanescent and persistent pruritic eruptions of adult-onset still disease: a clinical and pathologic study of 36 patients. Semin Arthritis Rheum 2012;42:317-26.

7. Sun NZ, Brezinski EA, Berliner J, et al: Updates in adult-onset Still disease: Atypical cutaneous manifestations and associations with delayed malignancy. J Am Acad Dermatol 2015;73:294-303.

8. Criado PR, de Carvalho JF, Ayabe LA, Brandt HR, Romiti R, Maruta CW: Urticaria and dermographism in patients with adult-onset Still's disease. Rheumatol Int 2012;32:2551-5.

9. Gerfaud-Valentin M, Maucort-Boulch D, Hot A, et al: Adult-onset still disease: manifestations, treatment, outcome, and prognostic factors in 57 patients. Medicine (Baltimore) 2014;93:91-9.

10. Lee JY, Yang CC, Hsu MM: Histopathology of persistent papules and plaques in adult-onset Still's disease. J Am Acad Dermatol 2005;52:1003-8. 